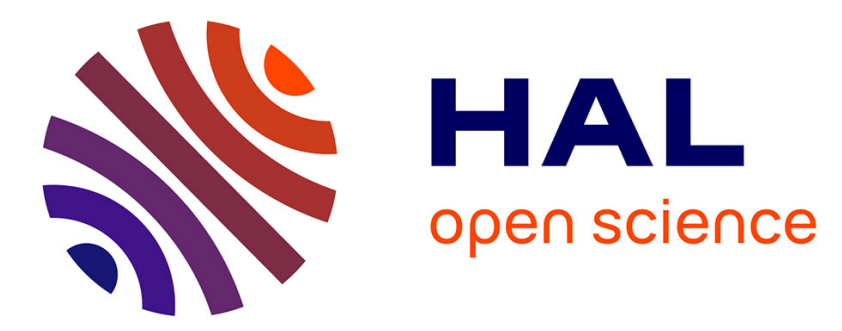

\title{
Fungal pathogen (mis-) identifications: A case study with DNA barcodes on Melampsora rusts of aspen and white poplar
}

Nicolas Feau, Agathe Vialle, Mathieu Allaire, Philippe Tanguay, David L. Joly, Pascal Frey, Brenda E. Callan, Richard C. Hamelin

\section{To cite this version:}

Nicolas Feau, Agathe Vialle, Mathieu Allaire, Philippe Tanguay, David L. Joly, et al.. Fungal pathogen (mis-) identifications: A case study with DNA barcodes on Melampsora rusts of aspen and white poplar. Mycological Research, 2009, 113 (6-7), pp.713-724. 10.1016/j.mycres.2009.02.007 . hal02658399

\section{HAL Id: hal-02658399 \\ https://hal.inrae.fr/hal-02658399}

Submitted on 30 May 2020

HAL is a multi-disciplinary open access archive for the deposit and dissemination of scientific research documents, whether they are published or not. The documents may come from teaching and research institutions in France or abroad, or from public or private research centers.
L'archive ouverte pluridisciplinaire HAL, est destinée au dépôt et à la diffusion de documents scientifiques de niveau recherche, publiés ou non, émanant des établissements d'enseignement et de recherche français ou étrangers, des laboratoires publics ou privés. 


\title{
Fungal pathogen (mis-) identifications: A case study with DNA barcodes on Melampsora rusts of aspen and white poplar
}

\author{
Nicolas FEAU ${ }^{a, *, 1}$, Agathe VIALLE ${ }^{a, b, 1}$, Mathieu ALLAIRE ${ }^{a}$, Philippe TANGUAY ${ }^{a}$, \\ David L. JOLY ${ }^{a}$, Pascal FREY ${ }^{c}$, Brenda E. CALLAN ${ }^{d}$, Richard C. HAMELIN ${ }^{a}$ \\ ${ }^{a}$ Laurentian Forestry Centre, Canadian Forest Service, Natural Resources Canada, 1055 du PEPS, PO Box 10380, Stn. Sainte-Foy, \\ Québec, QC, Canada G1V 4C7 \\ ${ }^{\mathrm{b}}$ Centre d'étude de la forêt, Université Laval, Québec, QC, Canada G1K 7P4 \\ 'INRA, Nancy-Université, UMR1136, Interactions Arbres - Microorganismes, 54280 Champenoux, France \\ dPacific Forestry Centre, Canadian Forest Service, Natural Resources Canada, 506 West Burnside Road, Victoria, BC, Canada V8Z 1M5
}

\section{A R T I C L E I N F O}

Article history:

Received 30 June 2008

Received in revised form

11 January 2009

Accepted 18 February 2009

Published online 26 February 2009

Corresponding Editor:

Gareth W. Griffith

Keywords:

Basidiomycota

DNA barcoding

Molecular phylogeny

Poplar leaf rusts

\begin{abstract}
A B S T R A C T
Wide variation and overlap in morphological characters have led to confusion in species identification within the fungal rust genus Melampsora. The Melampsora species with uredinialtelial stages on white poplar and aspens are especially prone to misidentification. This group includes the Melampsora populnea species complex and the highly destructive pine twisting rust, Melampsora pinitorqua, which alternates between hosts in Populus section Populus and Pinus. Our objective was to compare morphologically based identification to genetic material extracted from Melampsora species pathogenic to aspen and white poplar. We compared morphometric traits and DNA barcodes obtained from internal transcribed spacer (ITS), large ribosomal RNA subunit (28S), and mitochondrial cytochrome oxidase 1 (CO1) sequences to delimit within this taxonomically difficult group. Eight different Melampsora species were initially defined based on host specificity and morphometric data. DNA barcodes were then overlaid on these initial species definitions. The DNA barcodes, specifically those defined on ITS and 28S sequences, provided a highly accurate means of identifying and resolving Melampsora taxa. We highlighted species misidentification in specimens from Canadian herbaria related to either Melampsora medusae f. sp. tremuloidae or Melampsora aecidioides. Finally, we evidenced that the north-American species found on Populus alba, M. aecidioides is closely related but distinct from the four species of the M. populnea complex (Melampsora larici-tremulae, Melampsora magnusiana, Melampsora pinitorqua, and Melampsora rostrupii) found in Eurasia.

Crown Copyright @ 2009 Published by Elsevier Ltd on behalf of The British Mycological Society.
\end{abstract} All rights reserved.

\section{Introduction}

Reliable pathogen identification is a critical first step in assessing potential impact, disease risk and determining management options. Correct, taxonomically sound identification is particularly important for exotic and potentially invasive species since quarantine enforcement relies on proper diagnosis and rapid action (Desprez-Loustau et al. 2007). In this context, identification systems based on speciesspecific DNA sequences represent a significant advance for

\footnotetext{
* Corresponding author. INRA, UMR BioGeCo, BP 81, 71, avenue Edouard Bourlaux, 33883 Villenave d'Ornon Cedex, France.

E-mail address: nfeau@bordeaux.inra.fr

1 Contributed equally.
}

0953-7562/\$ - see front matter Crown Copyright @ 2009 Published by Elsevier Ltd on behalf of The British Mycological Society. All rights reserved. doi:10.1016/j.mycres.2009.02.007 
phytopathologists and taxonomists. The so-called DNA barcoding concept (Hebert et al. 2003) provides a rapid, cost-effective standardized means by which one can assess species identities. Though it is not without pitfalls (Moritz \& Cicero 2004; Waugh 2007), this system does offer the opportunity to scrutinize, at a fine scale level, taxonomic identification of morphologically similar specimens.

The Melampsora populnea (Pers.) P. Karst. complex is a group of morphologically similar rust fungi that produce their uredinial-telial stages on poplar species of the botanical section Populus (formerly Leuce), including P. tremula, P. alba, and their hybrids (Wilson \& Henderson 1966; Longo et al. 1975; Bagyanaryana 1998; Frey et al. 2005). The four species of this complex, Melampsora larici-tremulae Kleb., Melampsora magnusiana G. Wagner, Melampsora pinitorqua Rostr., and Melampsora rostrupii G. Wagner, share uredinial-telial host species but remain distinguishable by their spermogonial-aecial host specificity. M. pinitorqua represents an important forest threat due to stem infections on alternate pine (Pinus) (spermogonial-aecial stage) hosts, which cause twisting, deformation and death in young trees (Desprez-Loustau \& Dupuis 1992; Naldini-Longo et al. 1992). This fungus has not been reported in North America, apart from one record on Pinus ponderosa seedlings in a British Columbia (BC) nursery in the early 1960s (Ziller 1961, 1962). This identification was later judged questionable (Björkman 1964; Molnar \& Sivak 1964) and its reassessment was definitively made by Ziller himself few years after (Ziller 1974). No other documented report of $M$. pinitorqua in North America has been made since, albeit this fungus could represent a serious concern for many native pines. Indeed, epidemiologic studies conduced in areas infested by M. pinitorqua, have demonstrated the susceptibility of North American pines such as Pinus contorta, Pinus strobus, Pinus ponderosa, Pinus echinata, and Pinus taeda (Klingström 1963; Longo et al. 1975; Karlman 2001).

White poplar, Populus alba and its hybrids, are known to be immune to the common leaf rusts (Melampsora medusae f. sp. deltoidae Shain, Melampsora occidentalis H.S. Jacks., and Melampsora larici-populina Kleb.) found on North American poplars belonging to the botanical sections Aigeros and Tacahamaca. In Europe, P. alba is an important uredinial-telial host of rust species included in the M. populnea complex (including M. pinitorqua; Pinon 1973; Longo et al. 1975; Bagyanaryana 1998), whereas in North America, only Melampsora abietis-canadensis C.A. Ludw. and Melampsora aecidioides (DC.) J. Schröt. are mentioned on this host (Arthur 1962; Sinclair \& Lyon 2005). The name M. aecidioides has been erroneously used by different authors, and taxonomic placement of this species relative to other Melampsora rusts remains unclear. Arthur (1962) mentioned that the M. aecidioides species has been assigned to $M$. abietis-canadensis in his treatment of North American rusts. The former species has been considered by some authors as part of the M. populnea complex and is sometimes defined as being synonymous with M. rostrupii and M. magnusiana (Tian et al. 2004; Tian \& Kakishima 2005; Farr et al. 2008) or with M. populnea sensu lato (Van Vloten 1946; Savile 1973; Bagyanaryana 1998). As a consequence, $M$. populnea sensu lato has recurrently been attributed to leaf rusts encountered on P. alba and its hybrids in North and Central America (Hennen \& McCain 1993; Newcombe et al. 2001; Sinclair \& Lyon 2005).
Distinctive traits among pathogenic taxa are a key prerequisite to meaningful taxonomic classification, accurate identification and detection. This point appears specifically important when a number of supposedly related subspecies cause disease on the same host e.g. Melampsora rusts that produce their uredinial-telial stages on white poplars. By assessing the DNA barcoding concept of species identification proposed by Hebert et al. (2003), our aim was to address specific taxonomical questions about the M. populnea complex. The main practical objective of this work was to provide accurate and unambiguous data for the molecular identification of the highly destructive pathogen $M$. pinitorqua in order to detect any introduction of this pathogen in North America. The achievement of such objective needs to identify the rusts collected on poplars of the botanical section Populus in North America ( $P$. alba and aspen poplars, Populus tremuloides and Populus grandidentata) and eventually to differentiate them from M. pinitorqua. The DNA barcoding system developed in this study is based on a $650 \mathrm{bp}$ region at the $5^{\prime}$-end of the mitochondrial cytochrome oxidase 1 gene (5'-CO1). The sequence diversity among our Melampsora collections was further examined for the nuclear internal transcribed spacer (ITS) region of the nuclear ribosomal cistron (18S-5.8S-28S) and a portion of the large subunit of the ribosomal rDNA (28S), both commonly used as DNA-based discrimination systems for fungal species (Seifert et al. 2007).

\section{Material and methods}

\section{Sampling}

Twenty strains were directly sampled from fresh collections of aecia and uredinia. Nine dried collections obtained from four herbaria were also sampled (Table 1). Each specimen obtained had previously been assigned a species name based on the examiner's identification of the herbarium specimens and collector's identification of the fresh strains. All fresh strains collected were deposited at the René Pomerleau Herbarium (Laurentian Forestry Centre, Quebec City, http://cfs.rncan.gc.ca/index/pomerleauherbarium).

\section{Morphometrical analysis observations and urediniospores cluster analysis}

Aeciospores or urediniospores were mounted in a solution of cotton blue lactophenol (20 g phenol, 20 g lactic acid, 40 g glycerol, $200 \mathrm{ml}$ water, and $0.05 \mathrm{~g}$ cotton blue), and examined by light microscopy using a Reichart Polyvar microscope. For each Melampsora strain, 6 morphometric traits e.g. indirect length, width, and wall thickness measurements for 30 spores and 10 paraphyses were measured at $500 \times$ magnification. Paraphyses attributes were only determined if viewed longitudinally. The mean values obtained for each strain were plotted on a scatter plot 3D using SigmaPlot for Windows Version 10.0 (Systat Software).

Cluster and ordination analyses were used to explore the variation in morphometric traits. The data set 6 morphometric traits $\times 21$ OTU matrix of individual fungal specimens on uredinial stage) was entered directly into a computerised 
Table 1 - Fungal species and strains included in this study

\begin{tabular}{|c|c|c|c|c|}
\hline Identification $^{a}$ & Taxon ID & Host sampled & Geographic origin - spatial coordinates [date of sampling] & $\begin{array}{l}\text { Herbarium ID } \\
\text { [culture ref.] }\end{array}$ \\
\hline & 667-X-TSC-SH12 & T. canadensis & $\begin{array}{l}\text { St-Hippolyte, QC, Canada }-45^{\circ} 57^{\prime} 23^{\prime \prime} \mathrm{N} / 74^{\circ} 00^{\prime} 00^{\prime \prime} \mathrm{W} \\
\text { [2007-07-01] }\end{array}$ & \\
\hline & 418-MEA-POT-BE4 & Populus tremuloides & $\begin{array}{l}\text { Ste-Anne River, Montmorency Co., QC, } \\
\text { Canada }-47^{\circ} 04^{\prime} 00^{\prime \prime} \mathrm{N} / 70^{\circ} 52^{\prime} 00^{\prime \prime} \mathrm{W}[1960-08-18]\end{array}$ & QFB 18187 \\
\hline & 570-MEA-X-ON38 & $\begin{array}{l}\text { Populus alba } \\
\text { var. pyramidalis }\end{array}$ & 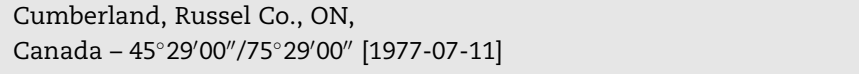 & DAOM 164840 \\
\hline \multirow[t]{5}{*}{ Melampsora sp. on P. alba } & 380-ME-PO-BC7 & P. alba & $\begin{array}{l}\text { Jericho Beach, Vancouver, BC, } \\
\text { Canada - } 49^{\circ} 16^{\prime} 28^{\prime \prime} \mathrm{N} / 123^{\prime} 13^{\prime} 41^{\prime \prime} \mathrm{W} \text { [2006-10-13] }\end{array}$ & \\
\hline & 664-ME-POA-BC45 ${ }^{\mathrm{b}}$ & P. alba & Colquitz Creek, BC, Canada $-48^{\circ} 27^{\prime} 32^{\prime \prime} \mathrm{N} / 123^{\circ} 23^{\prime} 40^{\prime \prime} \mathrm{W}$ [2007-06-19] & \\
\hline & 665-ME-POA-BC46 ${ }^{\mathrm{b}}$ & P. alba & Colquitz Creek, BC, Canada - 48 $27^{\prime} 32,12^{\prime \prime} \mathrm{N} / 123^{\circ} 23^{\prime} 40^{\prime \prime} \mathrm{W}$ [1992-04-22] & DAVFP 24319 \\
\hline & 899-MEI-POA-VC1 ${ }^{\text {b }}$ & P. alba & Colquitz Park, Victoria, BC, Canada $-48^{\circ} 27^{\prime} 32^{\prime \prime} \mathrm{N} / 123^{\circ} 23^{\prime} 40^{\prime \prime} \mathrm{W}$ [2007-11] & [Ma07VIC01] \\
\hline & 900-MEI-POA-VC2 ${ }^{\mathrm{b}}$ & P. alba & Colquitz Park, Victoria, BC, Canada - $48^{\circ} 27^{\prime} 32^{\prime \prime} \mathrm{N} / 123^{\circ} 23^{\prime} 40^{\prime \prime} \mathrm{W}$ [2007-11] & [Ma07VIC02] \\
\hline \multirow{2}{*}{ Melampsora magnusiana } & 1330-MEG-CJ-FI & Chelidonium majus & Turku, Regio aboënsis, Finland - [1936-06-14] & BPI0023740 \\
\hline & 1331-MEG-CJ-SW & C. majus & Vardsatra, Uppsala, Sweden - [1964-06-14] & BPI 193858 \\
\hline Melampsora rostrupii & 01G1 & Mercurialis perennis & Gorze, Moselle, France $-49^{\circ} 03^{\prime} \mathrm{N} / 06^{\circ} 00^{\prime} \mathrm{E}[2001-05-12]$ & \\
\hline \multirow[t]{6}{*}{ Melampsora pinitorqua } & 902-MEM-PNM-TW $1^{\mathrm{d}}$ & Pinus ponderosa & Telkwa, BC, Canada - [1960-07-11] & DAVFP 12177 \\
\hline & 903-MEM-PNM-TW2 ${ }^{\mathrm{d}}$ & P. ponderosa & Telkwa, BC, Canada - [1960-07-08] & DAVFP 12464 \\
\hline & 97MP10 & Pinus sylvestris & Charmes, Vosges, France $-48^{\circ} 23^{\prime} 56^{\prime \prime} \mathrm{N} / 06^{\circ} 22^{\prime} 45^{\prime \prime} \mathrm{E}$ [1997-06] & \\
\hline & 97MP08 & P. sylvestris & Charmes, Vosges, France $-48^{\circ} 23^{\prime} 56^{\prime \prime} \mathrm{N} / 06^{\circ} 22^{\prime} 45^{\prime \prime} \mathrm{E}$ [1997-06] & \\
\hline & 97MP09 & P. sylvestris & Charmes, Vosges, France $-48^{\circ} 23^{\prime} 56^{\prime \prime} \mathrm{N} / 06^{\circ} 22^{\prime} 45^{\prime \prime} \mathrm{[1997-06]}$ & \\
\hline & $00 \$ 1$ & P. tremula & Cestas, Gironde, France $-44^{\circ} 44^{\prime} \mathrm{N} / 00^{\circ} 46 \mathrm{~W}[2000]$ & \\
\hline \multirow[t]{2}{*}{ Melampsora sp. on P. tremula } & 892-MPO-PTA-FR3 & P. tremula & $\begin{array}{l}\text { Cornebarrieu, Haute-Garonne, } \\
\text { France }-43^{\circ} 38^{\prime} 45^{\prime \prime} \mathrm{N} / 01^{\circ} 15^{\prime} 28^{\prime \prime} \mathrm{E} \text { [2006-09-23] }\end{array}$ & \\
\hline & 893-MPO-PTA-FR4 & P. tremula & $\begin{array}{l}\text { Cornebarrieu, Haute-Garonne, } \\
\text { France }-43^{\circ} 38^{\prime} 45^{\prime \prime} \mathrm{N} / 01^{\circ} 15^{\prime} 28^{\prime \prime} \mathrm{E} \text { [2006-09-23] }\end{array}$ & \\
\hline
\end{tabular}




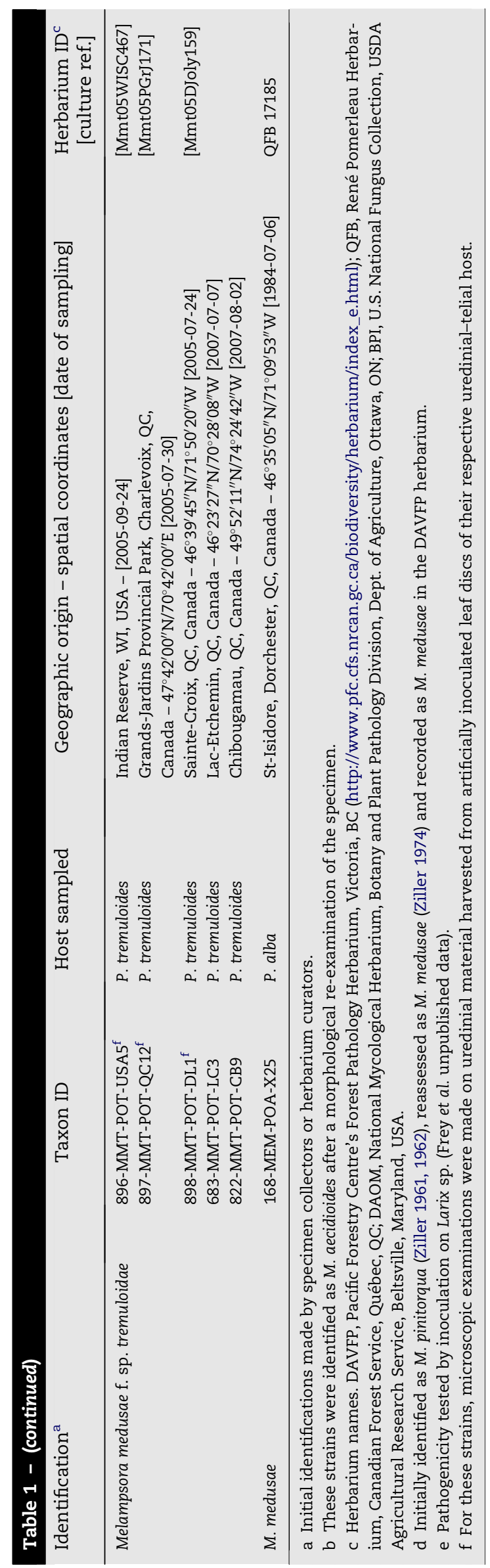

matrix and a cluster analysis was performed using the $\mathrm{R}$ statistical software ( $R$ Development Core Team 2008). Prior to multivariate analysis, the data were log-transformed to meet the assumption of normality. All 11 variables were then standardized by subtracting the mean and dividing by the standard deviation to avoid biasing the result by a scale factor (Sokal 1986). A similarity matrix was calculated from the standardized data set using the general dissimilarity coefficient of Gower (1971). The Gower's method presents the advantage that OTU with missing observations can be included for comparison with the other OTU (Dabinett \& Wellman 1978). A phenogram was finally generated using the complete linkage clustering algorithm (Dabinett \& Wellman 1978).

\section{DNA barcodes production}

For each strain, a single sorus (uredinium or aecium) was excised from the infected host tissues, and DNA extraction was performed using the DNeasy Plant Mini kit (Qiagen). Manufacturer's protocol was followed except that following tissue homogenization, the proteinase $\mathrm{K}(0.5 \mathrm{mg} / \mathrm{ml})$ incubation step at $55^{\circ} \mathrm{C}$ was increased to $2 \mathrm{~h}$.

Full length internal transcribed spacer (ITS) sequences were amplified by using primers ITS1F (Gardes \& Bruns 1993) and ITS4BR (5'-TCAACAGACTTGTACATGGTCC-3'; Morin et al. unpublished data). A $755 \mathrm{bp}$ internal region of the large subunit of the ribosomal DNA (28S) was amplified using the ITS4-BRf (5'-GGACCATGTACAAGTCTGTTGA-3') and LR5 primers (Vilgalys and Hester, 1990). PCRs were carried out in a $25 \mu \mathrm{l}$ reaction volume consisting of $1 \mu \mathrm{l}$ of undiluted DNA template, $0.35 \mu \mathrm{M}$ of each primer, $0.2 \mathrm{mM}$ of each dNTPs (GE Healthcare UK \& Ireland, Little Chalfont, UK), $1.6 \mathrm{mM} \mathrm{MgCl}_{2}, 1 \mu \mathrm{g} \mu \mathrm{l}^{-1}$ of BSA, and $1 \mathrm{U}$ of Platinum Taq DNA polymerase (Invitrogen) in a $1 \times$ Taq DNA polymerase buffer $(20 \mathrm{mM}$ Tris- $\mathrm{HCl}, \mathrm{pH}$, and $50 \mathrm{mM}$ $\mathrm{KCl})$, with thermocycling conditions as follows: denaturation for $3 \mathrm{~min}$ at $94^{\circ} \mathrm{C}$, 35 cycles at $94^{\circ} \mathrm{C}$ for $30 \mathrm{~s}, 30 \mathrm{~s}$ at $50^{\circ} \mathrm{C}$ for the ITS1F/ITS4BR primer pair or at $55^{\circ} \mathrm{C}$ for ITS4-BRf/LR5, and $72{ }^{\circ} \mathrm{C}$ for $70 \mathrm{~s}$ with a final extension of $10 \mathrm{~min}$ at $72^{\circ} \mathrm{C}$. Two primer pairs, Cox1MlpAF (5'-TAAGATGACTTTATAGTACCAA-3')/ Cox1MlpAR (5'-GCTCCTACCATTACMG-3') and Cox1MlpB2F (5'-CTGCTATGCCCAAGTCTAA-3')/Cox1MlpCR (5'-ATGTGATG ACTTCAAACCAC-3'), designed by comparison of rust $\mathrm{CO} 1$ sequences (Vialle et al. unpublished data), were used for the amplification of two composite overlapping regions located at the $5^{\prime}$-end of the $\mathrm{CO} 1$ gene $\left(5^{\prime}\right.$-CO1). PCRs were carried out in a $20 \mu \mathrm{l}$ reaction volume consisting of $1 \mu$ l of undiluted DNA template, $0.2 \mu \mathrm{M}$ of each primer, $0.15 \mathrm{mM}$ of each dNTPs (GE Healthcare UK \& Ireland), $1.5 \mathrm{mM} \mathrm{MgCl}_{2}$, and $1 \mathrm{U}$ of platinum Taq DNA polymerase (Invitrogen) in a $1 \times$ Taq DNA polymerase buffer (20 mM Tris-HCl, $\mathrm{pH} 8$, and $50 \mathrm{mM} \mathrm{KCl}$ ), with conditions as follows: denaturation for $3 \mathrm{~min}$ at $95^{\circ} \mathrm{C}, 36$ cycles at $95^{\circ} \mathrm{C}$ for $45 \mathrm{~s}, 47^{\circ} \mathrm{C}$ for $30 \mathrm{~s}$ with primer pair Cox1MlpAF/Cox1MlpAR or $50.5^{\circ} \mathrm{C}$ for $30 \mathrm{~s}$ with Cox1MlpB2F/Cox1MlpCR, and $72^{\circ} \mathrm{C}$ for $70 \mathrm{~s}$. All PCR products were visualized by ultra-violet fluorescence following $1.5 \%$ agarose gel eletrophoresis in $1 \times \mathrm{TAE}$ buffer and ethidium bromide staining. PCR sequence products were sequenced in both directions with the appropriate amplification primers using the Big Dye Terminator Cycle Sequencing Kit us. 1.1 on an ABI 3730xl sequencer (Applied 
Biosystems) at the CHUL Research Centre (CRCHUL) Sequencing and Genotyping Platform, Quebec City, QC, Canada.

\section{DNA barcodes analysis}

Sequences were manually edited using BioEdit v.7.0.9 (Hall 1999) to remove ambiguous base calls and primer sequences, and were then aligned using the CLUSTALW software (Thompson et al. 1994). Sequence information is available in the Barcode of Life Database (BOLD, www.barcodinglife.org), along with collateral information. Kimura's two-parameter model (K2P) of base substitution implemented in PAUP ver. 4.0b10 (Swofford 2003) was used to calculate intra- and inter-specific genetic distances. Distribution of these two categories of distances was plotted for each gene using the Boxplot representation of Tukey (1977).

\section{Phylogenetic analysis}

Maximum likelihood trees were reconstructed among each data set using PAUP ver. 4.0b10. All nucleotide sites were included in the phylogenetic analyses but gaps were treated as missing characters. The best-fit model of DNA substitution and the parameter estimates used for tree reconstruction were chosen by performing hierarchical likelihood-ratio tests in Modeltest v. 3.06 (Posada \& Crandall 1998). Heuristic Maximum Likelihood (ML) searches were performed with 100 replicates of random sequence addition and tree bisectionreconnection (TBR) branch swapping. Branch support was evaluated using 100 bootstrap replicates and 10 random additions of sequences (RAS) per pseudo-replicate. Topological incongruences between ML trees were evaluated by inspecting strength of bootstrap support for individual branches as described in Feau et al. $(2006,2007)$.

\section{Results}

\section{Morphological observation and urediniospores cluster analysis}

Morphometric traits of all the strains were recorded through microscopic examinations and compared to data found in the literature (Fig 1A). The observation of ellipsoid to obovate aeciospores with fine verrucose surfaces (16.3-17.3 $\times$ 19.5-19.7 $\mu \mathrm{m})$ agreed with published descriptions of Melampsora abietis-canadensis (Arthur 1962), confirming the identification of two strains (666-X-TSC-SH11, 667-X-TSCSH12) whose preliminary identification was based on specificity with their spermogonial-aecial host, Tsuga canadensis (Ludwig 1915; Arthur 1962). Morphometric values obtained for the $M$. abietis-canadensis strains (418-MEA-POT-BE4, 894-MEA-POT-DO1, and 895-MEA-POT-SU5) collected on Populus tremuloides (uredinial-telial stage) matched those described in the literature for this species (Arthur 1962; Shain 1988). However, the strains 894-MEA-POT-DO1 and 895MEA-POT-SU5 showed strong urediniospore similarities (urediniospores ellipsoid or obovoid, with wall as aeciospores, and with smooth areas at the equator, 13-21 $\times 22-36 \mu \mathrm{m}$ ) with three Melampsora medusae f. sp. tremuloidae strains
(822-MMT-POT-CB9, 896-MMT-POT-USA5, and 898-MMTPOT-DL1), underlining the overlap in urediniospore sizes between the latter species and M. abietis-canadensis (Fig 1B). Urediniospore shapes and echinulations observed for the six rust strains collected in BC on Populus alba (380-ME-PO-BC7, 664-ME-POA-BC45, 665-ME-POA-BC46, 899-MEI-POA-VC1, 900MEI-POA-VC2, and 901-MEI-POA-VC3) strongly matched those described for Melampsora aecidioides e.g. urediospores obovate or broadly ellipsoid, wall yellowish or colorless, 2-3 $\mu \mathrm{m}$ thick, prominently echinulate-verrucose, without smooth spot (Arthur 1962). These strains exhibited values of urediniospore lengths and widths that sometimes overlapped with values observed and expected for Melampsora larici-tremulae, Melampsora pinitorqua, and Melampsora rostrupii. Ordination obtained from the cluster analysis agreed with these observations since the strains collected on P. alba were found dispersed in various clusters, grouping with the different strains related to the Melampsora populnea species complex (M. larici-tremulae, M. pinitorqua, and M. rostrupii) (Fig 1B). Such variation in urediospore length and width was expected for M. aecidioides $(15-22 \times 20-30 \mu \mathrm{m}$, Arthur 1962). Other species of the M. populnea complex exhibit less variation with small (M. pinitorqua and M. larici-tremulae, 10-16 × 14-23 $\mu \mathrm{m}$; Melampsora magnusiana, 10-16 × 14-23 $\mu \mathrm{m}$; and $M$. rostrupii, 14-18 $\times 17-28 \mu \mathrm{m})$ and ovoid to globular urediniospores (Pinon 1973). Furthermore, we observed that all six Melamspora on P. alba strains produced large paraphyses with length, width, and wall thickness values of 56-77 $\mu \mathrm{m}$ (mean $66.7 \mu \mathrm{m} \pm 12.3$ ), $16-27 \mu \mathrm{m}$ (mean $20.3 \mu \mathrm{m} \pm 3.9$ ), and $1.2-4 \mu \mathrm{m}$ (mean $2.9 \mu \mathrm{m} \pm 12.3$ ), respectively (Supplementary File 1). Large paraphyses had previously been described for both $M$. aecidioides (40-60 × 15-22 $\mu \mathrm{m}$; Saccardo 1888) and M. rostrupii (Pinon 1973). Based on host affinity with Populus tremula, strains 892-MPO-PTA-FR3 and 893-MPO-PTA-FR4 were determined to belong to the M. populnea complex (Wilson \& Henderson 1966; Pinon 1973; Frey et al. 2005). However, as illustrated by the results obtained with the ordination analysis (Fig 1B), the morphological traits of the uredinial-telial stages are not sufficiently distinctive to allow a straightforward identification of the different species belonging to the M. populnea complex.

\section{Barcode analysis}

Sequence data for the ITS, 28S, and 5'-CO1 regions were recovered for all 32 strains of our collection. Based on the initial definition of the nine different morphological and host-specific species, 60 intra- and 436 inter-specific pairwise sequence comparisons were performed for each of the three data sets. The magnitude of these pairwise K2P distances varied with the locus considered. Distance values ranged from 0.0 to 0.099 for ITS, $0.0-0.052$ for $28 \mathrm{~S}$, and were limited to $0.0-0.005$ for $5^{\prime}-\mathrm{CO} 1$ (Fig 2A). Following the concatenation of the ITS, 28S, and $5^{\prime}$-CO1 loci, the distance values (0.0-0.048) appeared uniformly lower than those for the ITS or the $28 \mathrm{~S}$ alone. Large overlaps were observed between the upper quartile of the intra- and the lower quartile of the inter-specific distance distributions for each data set (ITS, 28S, $5^{\prime}$-CO1, and concatenated). Outlier data above the inter-specific distributions witnessed the presence of genetically divergent (K2P distance $>0.02$ ) lineages within $M$. abietis-canadensis (subdivided into three groups with $\mathrm{K} 2 \mathrm{P}$ distances ranging from 0.016 to 0.04 ) and M. pinitorqua (subdivided into two groups with $\mathrm{K} 2 \mathrm{P}$ distances $=0.02$ ) 
A

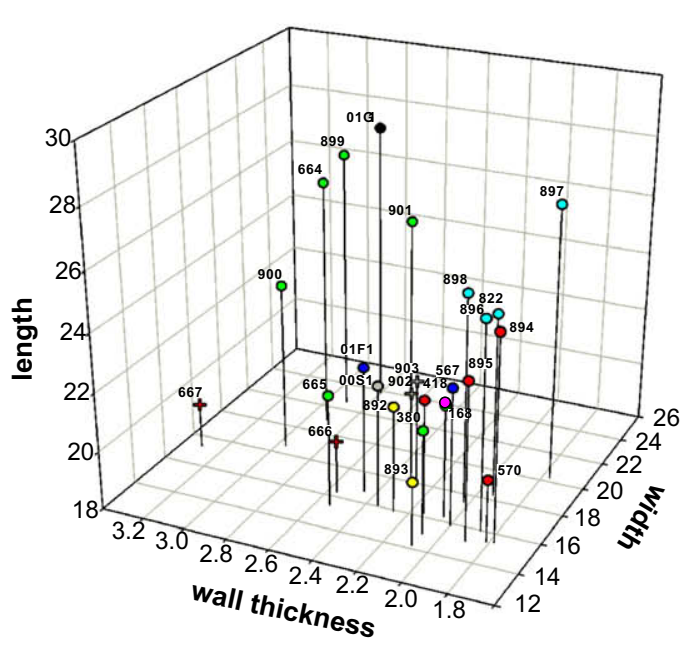

Spore sizes expected according to the literature Spore name $=$ length $\mathrm{x}$ width $/$ thickness in $\mu \mathrm{m}$ Aeciospores $=17-26 \times 13-18 / 1-2($ Arthur 1962)

+ M. abietis-canadensis

- M. abietis-canadensis

- Melampsora sp. on P. alba

- M. larici-tremulae

○ M. medusae f. sp. tremuloidae

- M. medusae

+ M. pinitorqua

- M. pinitorqua

- Melampsora sp. on P. tremula

- M. rostrupii
B

$\begin{array}{lllll}0.8 & 0.6 & 0.4 & 0.2 & 0.0 \\ i\end{array}$

Fig 1 - Morphometrical traits of the different Melampsora strains considered in this study. (A) Morphometry scatter plot 3D of aeciospore and/or urediniospore length, width, and wall thickness. Colored circles and crosses represent urediniospores and aeciospores, respectively. The number above each symbol corresponds to the three first characters of the Taxon ID in Table 1. (B) Cluster analysis of the different strains according to urediniospore and paraphyse lengths, widths, and wall thickness.

(Fig 3). Conversely, the observation of K2P distances close to 0.0 within the inter-specific comparison suggested the occurrence of conspecific strains previously recognized as different morphological species. Using the multilocus DNA barcoding, seven misidentifications were highlighted among the 29 strains analysed (i.e. $24 \%$ of all samples analysed) (Fig 3). A first lineage within M. abietis-canadensis exhibited a K2P distance of 0.0 with the six strains collected on $P$. alba and previously identified as M. aecidioides and the M. medusae strain 168-MEM-POA-X25; a second lineage, which includes three $M$. abietis-canadensis strains (894MEA-POT-DO1, 895-MEA-POT-SU5, and 418-MEA-POT-BE4) and two M. pinitorqua strains (902-MEM-PNM-TW1 and 903-MEMPNM-TW2), exhibited K2P distance values ranging from 0.0 to 0.001 with the five M. medusae f.sp. tremuloidae strains. Inter-specific distances within the M. populnea complex were found close to 0.0 for comparisons between M. pinitorqua, M. larici-tremulae, and the strains collected on P. tremula. Only two single nucleotide polymorphisms (SNPs) localized in the ITS and 28S loci were found between the M. pinitorqua and M. larici-tremulae strains. Both SNPs were found heterozygotous for the M. larici-tremulae strains (Y e.g. C or T for both), with thus in each case one allele strictly identical to the $M$. pinitorqua genotype ( $C$ and $T$ in the ITS and the $28 \mathrm{~S}$ respectively). Similarly, M. rostrupii and M. magnusiana exhibited two SNPs localized in the ITS loci and notably low K2P distance values which varied from 0.0 to 0.096 depending on the locus considered. The sequences from the six strains collected on P. alba and previously identified as M. aecidioides clustered in one single molecular group with K2P distances of 0.0. Five distinct molecular species were resolved using the combined sequence data from the ITS, 28S, and 5'-CO1 loci (Fig 3).

Following the species reassignment of the seven misidentified strains, intra- and inter-specific pairwise distance distributions were re-examined (Fig 2B). The intra-specific distribution increased to 108 comparisons, whereas inter-specific decreased to 388. For each data set, a complete absence of overlap was observed between the intra- and inter-specific distributions. The combined data set yields the best result for sequence-based identification analysis despite its limited range of distance values relative to the ITS data set. By combining the three loci, the variation within species circumscriptions is reduced (to a value of $3 \mathrm{e}^{-04}$ ) relative to the distance between species (Fig 2B). 


\section{Phylogenetic analysis}

Maximum likelihood (ML) analyses of each separate data set, using the reciprocal $70 \%$ bootstrap threshold (Feau et al. 2006, 2007), resulted in topologically congruent trees (data not shown). The phylogenetic analysis conducted on the combined ITS, 28S, and 5'-CO1 data sets resulted in apparent good level of resolution with only one single tree obtained $(-\mathrm{Ln}=3745)$ (Fig 4A). The analysis resolved five different phylogenetic species with a bootstrap support (BS) up to $90 \%$. The four species of the M. populnea complex were partially resolved: $M$. larici-tremulae and $M$. pinitorqua were unresolved within one single and well-supported ( $\mathrm{BS}=100 \%$ ) monophyletic clade; M. rostrupii (strain 01G1) and M. magnusiana were also found unresolved in one statistically supported clade $(B S=99 \%)$ and appeared more related to the $M$. aecidioides clade $(B S=100 \%)$ than the other members of the complex. Eleven additional ITS and 28S sequences representing four additional Melampsora species collected on white poplar and aspen were downloaded from the non-redundant GenBank database and included in an ITS/28S ML phylogeny (Fig 4B-C). ML phylogenetic reconstruction resulted in six trees of equal length $(-\mathrm{Ln}=2254)$ (Fig 4B). No additional phylogenetic species was resolved following the addition of these 11 taxa. Five strains labelled as either M. populnea (strain AAH00-1; Pei et al. 2005) or M. magnusiana (Liang et al. 2006) clustered with the $M$. aecidioides clade (BS $=89 \%$ ). The M. laricis (synonym M. larici-tremulae) strain (TSH R4149; Liang et al. 2006) matched the M. pinitorqua/M. larici-tremulae clade. The five last unidentified strains (Melampsora sp.; Tian et al. 2004) were distributed among the M. aecidioides, M. rostrupii/ M. magnusiana, and M. pinitorqua/M. larici-tremulae clades.

\section{Discussion}

Exact species identification of fungal pathogens is important in plant pathology since misidentification may lead to erroneous management advice. This is especially true for the aspen and white poplar leaf rusts, which include the highly destructive Melampsora pinitorqua involved in pine plantation outbreaks in Europe (Desprez-Loustau \& Dupuis 1992; Naldini-Longo et al. 1992). Given the potential dangerous impact of pine twist rust on forest trees in North America, eradication of this disease and prevention of re-infection in the case of its occurrence may involve drastic strategies such as total destruction of infected pine plantations. For example, the recommended destruction of contaminated ponderosa pine seedlings from a BC nursery following the morphological identification of M. pinitorqua rust (Ziller 1962) was later questioned. Indeed, Molnar \& Sivak (1964) successfully infected ponderosa pines with basidiospores from different strains of the poplar leaf rust Melampsora albertensis Arthur (synonym = Melampsora medusae [Ziller 1965, 1974]), which led them to hypothesise that the disease recorded earlier
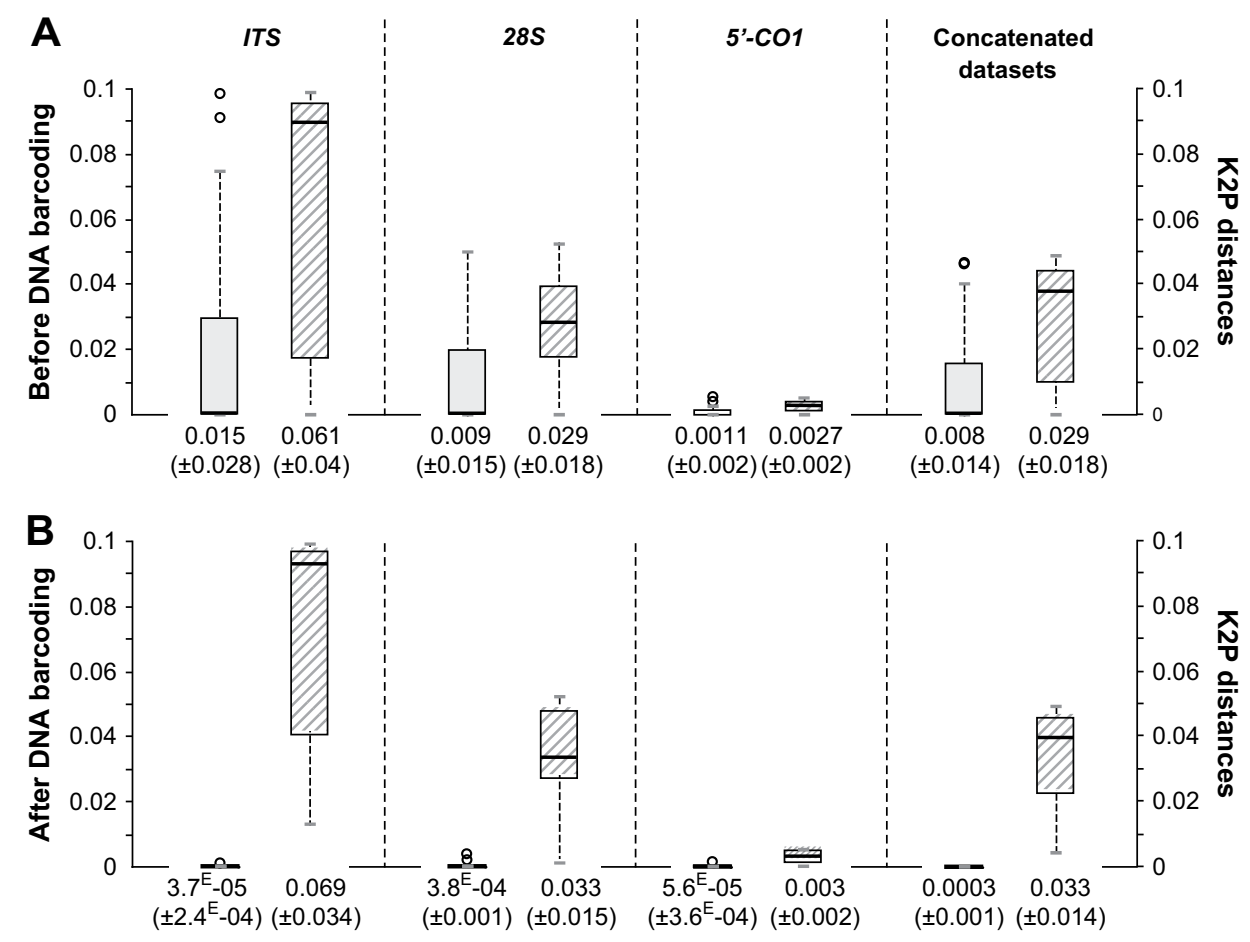

Intraspecific comparisons $\square$ Interspecific comparisons

Fig 2 - Boxplot distributions of intra-specific (60 comparisons) and inter-specific (436 comparisons) K2P distances between sequence pairs of the ITS, 28S, and 5'-CO1 genes for the 32 Melampsora strains included in this study. Distances were considered using species delimitation based on (A) morphological traits and host affinities, and (B) DNA barcoding criteria. Boxplot representations include the median (central bar), the position of the upper and lower quartiles (called Q1 and Q3; central box), extremes of the data ("whiskers") and very extreme points that can be considered as outliers (dots; points that exceed $Q 1+1.5 I Q R$ and $Q 1-1.5 I Q R$ for the upper and lower parts of the distribution, respectively, where $I Q R=Q 3-Q 1)$. 


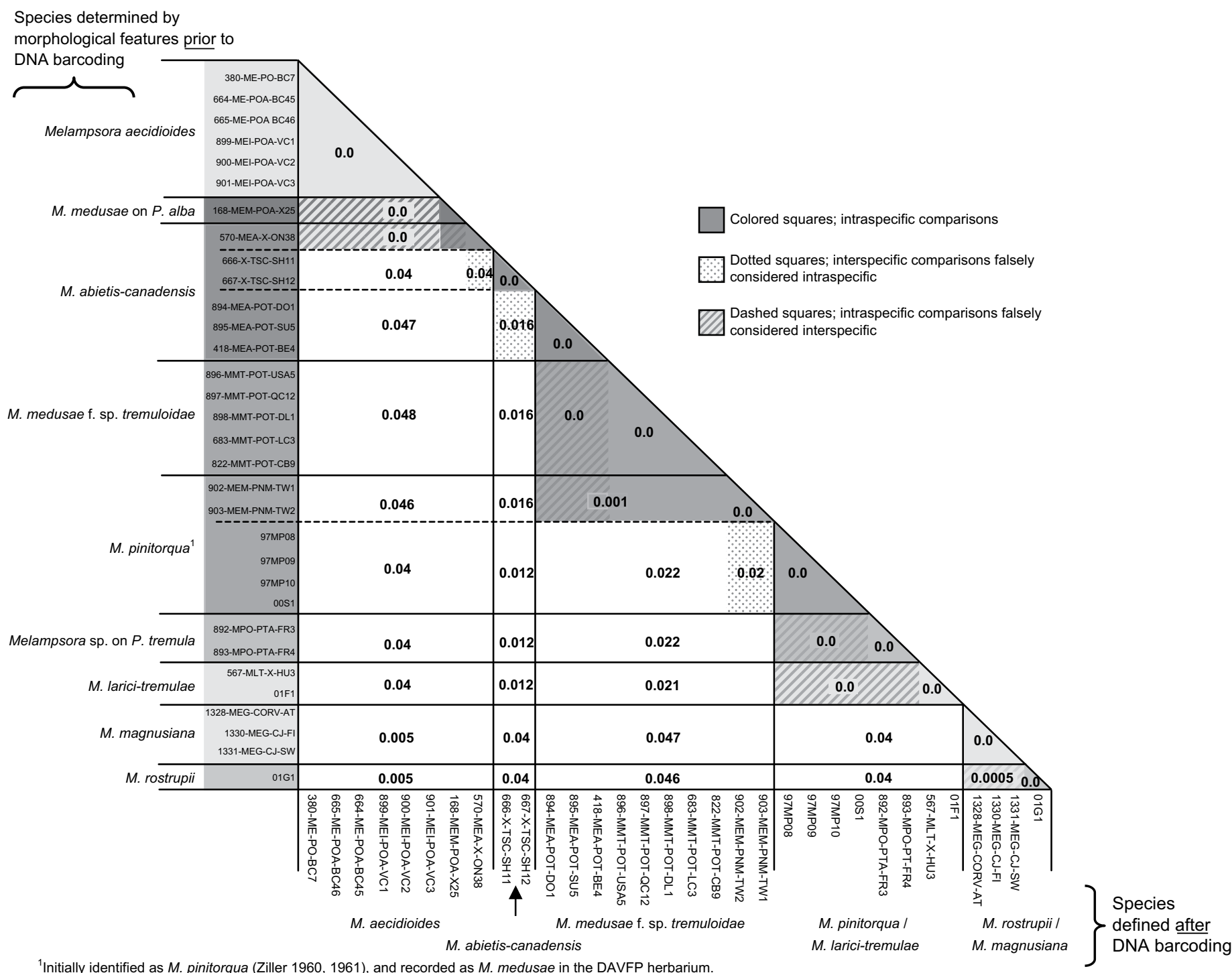

Fig 3 - Matrix of pairwise intra- and inter-specific K2P distances obtained with a DNA barcoding system based on the concatenated ITS, $28 \mathrm{~S}$, and 5'-CO1 loci for 32 Melampsora strains. 
(Ziller 1961, 1962) was caused by the indigenous M. medusae and not by the European pine twist rust M. pinitorqua. Ziller himself (1974) made a reassessment of this identification few years after and finally described the fungus occurring on ponderosa pines as M. medusae. Using our DNA barcode assay, we also determined that the two herbarium specimens collected on Pinus ponderosa in 1960-1961 (Ziller 1961) were undoubtedly distinct from reference strains of $M$. pinitorqua collected in Europe on both aecial (pines) and telial (poplars) hosts. As expected, we found strong homology between the putative North American M. pinitorqua sequences and those obtained for $M$. medusae f. sp. tremuloidae (K2P distance $=0.001$ ), which produces its uredinial-telial stage on trembling and bigtooth aspen (Shain 1988) and its spermogonial-aecial stage on larches (Larix spp.), Douglas-fir (Pseudotsuga menziesii) and pines (Molnar \& Sivak 1964; Ziller 1965). Our microscopic observations of the herbarium specimens collected by Ziller (1961) showed that the size ranges and characteristics of aeciospores fit both $M$. pinitorqua and $M$. medusae. These results were in accordance with those from Molnar \& Sivak (1964) who reported that morphologies of the M. pinitorqua and M. medusae aeciospores found on pines did not differ sufficiently to distinguish these two species, resulting sometimes in unreliable disease identification. Surprisingly, the delimitation between the Melampsora larici-tremulae (synonym $=M$. laricis) strains obtained in this study and $M$. pinitorqua appeared less straightforward than expected. M. larici-tremulae and $M$. pinitorqua are distinguishable by their spermogonial-aecial host specificity on larch and pine, respectively. Moreover, they differ in minute (and sometimes hard to detect) microscopic details such as wall thickness at the urediniospore equator (Hennebert 1964; Pinon 1973). Based on an alignment of three loci representing 2130 nucleotides, only two SNPs (heterozygotous in M. larici-tremulae) were found between both species. Morphological determinations of the two $M$. larici-tremulae strains included in this study were based first on urediniospore and paraphyses characters and second for the 01F1 strain, on successful inoculation on larch, the spermogonial-aecial host (Frey et al. unpublished data). Similarly, identification of strains from pines with similar DNA sequences will allow irrevocably the diagnostic of M. pinitorqua. Given the risks associated with the introduction of this fungus on North American pines (at less five potentially susceptible pine species), the availability of reference DNA barcodes for $M$. pinitorqua should now avoid

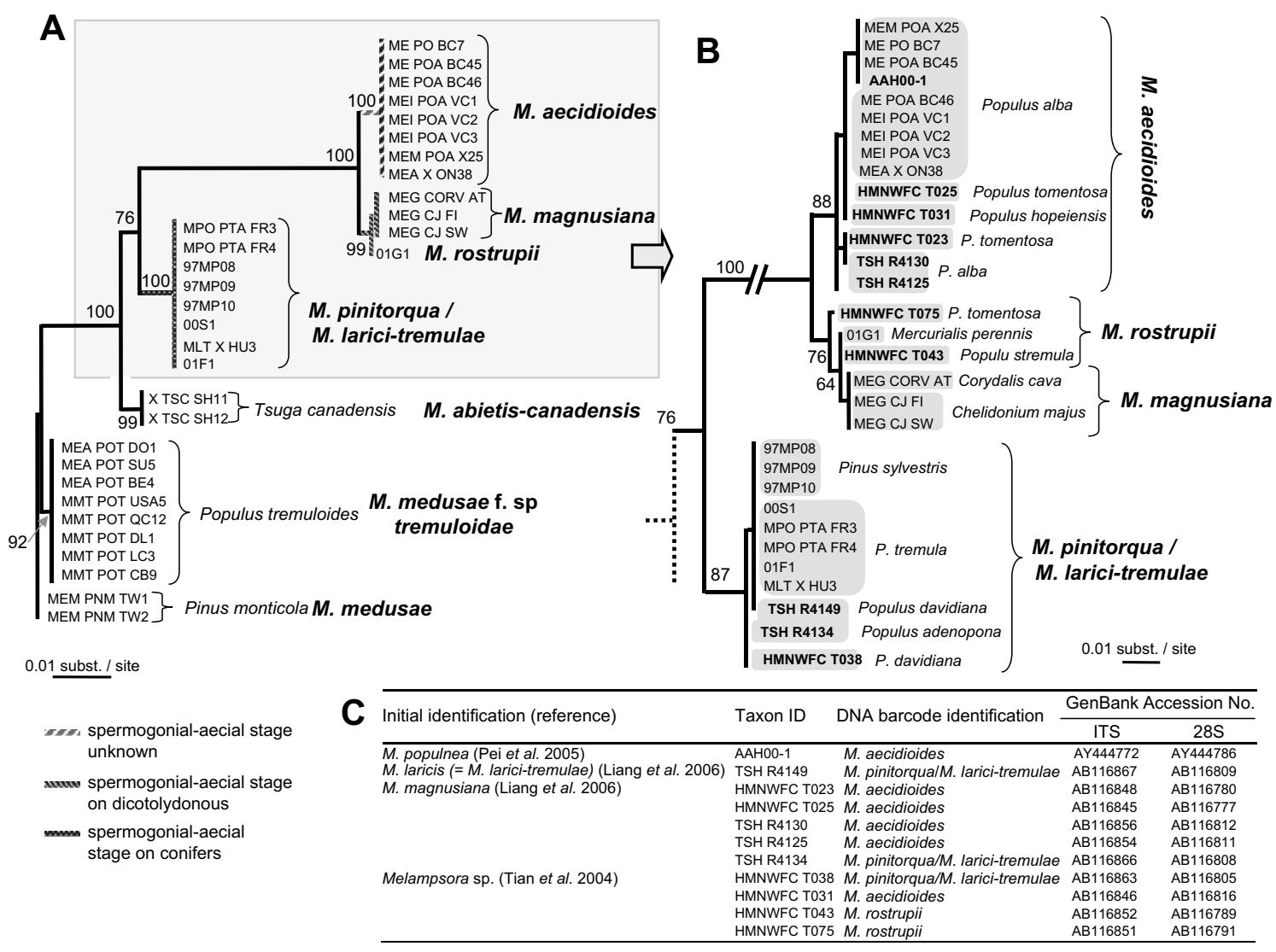

Fig 4 - Phylogenetic relationships among Melampsora species from aspen and white poplar. (A) ITS $+28 \mathrm{~S}+5^{\prime}$-CO1 maximum likelihood tree based on a K81uf + G substitution model (assuming a proportion of invariable site parameters equal to 0.014). (B) ITS + 28S maximum likelihood tree, including GenBank sequences (in bold) from rust strains infecting aspen and white poplar; tree reconstruction was based on a $\mathrm{K} 81 \mathrm{uf}+\mathrm{G}$ substitution model (assuming a gamma distribution of rate variation among sites equal to 0.024). (C) Attributes (including ITS and 28S sequences accession numbers) of 11 rust strains infecting white poplar and aspen downloaded from the GenBank database. 
erroneous diagnostic and drastic phytosanitary advices which could arose.

Microscopic investigations led us to believe that the leaf rust strains we obtained from Populus alba in Canada exhibited traits of Melampsora aecidioides (Arthur 1962). This species has a worldwide distribution; occurrences have been reported from the eastern and western parts of North America (Arthur 1962), South Africa (Roberts \& Mitchell 1979) and Asia (Cummins 1943; Tian \& Kakishima 2005). Considering its morphological traits and its ability to grow on P. alba, numerous authors have included M. aecidioides in the Melampsora populnea complex, and have considered $M$. aecidioides to be synonymous with either Melampsora magnusiana (=Melampsora pulcherrima Maire) or Melampsora rostrupii (Tian et al. 2004; Tian \& Kakishima 2005). Using only morphological traits of the uredinial-telial stage (on Populus tremula and P. alba) to distinguish M. magnusiana from the three other species of the M. populnea complex, particularly from M. rostrupii, is contentious (Pinon 1973; Frey et al. 2005; Sinclair \& Lyon 2005). However, M. rostrupii and M. magnusiana appear to be distinctive members of the $M$. populnea species complex because their spermogonial-aecial stages are pathogenic to Mercurialis perennis and to Papaveraceae (Chelidonium sp., Fumaria sp., and Corydalis sp.) respectively (Pinon 1973; Naldini-Longo et al. 1985; Desprez-Loustau 1986; Sinclair \& Lyon 2005). From a phylogenetic perspective, we acquired strong evidence that $M$. aecidioides is closely related but clearly distinct to both $M$. rostrupii and M. magnusiana (K2P distance $=0.005$ ). The two former species remained undifferentiated in one single monophyletic clade (Fig 4A; BS = $99 \%$ ). Pairwise genetic divergence among $M$. magnusiana and $M$. rostrupii showed a small divergence between these species $(\mathrm{K} 2 \mathrm{P}$ distance $=0.0005$; two SNPs over the 2130 nucleotides analysed), quite similar to the average within species divergences (K2P distance $=0.0003$ ) in the other Melampsora species considered. The divergence observed in these three nuclear loci, appears however not enough to differentiate some close taxa initially defined with host specificities and morphology, as conspecifics. There are several reasons why phenotypic and molecular traits do not completely agree, one of these being incomplete lineage sorting (Freeland 2006; Maddison \& Knowles 2006). Here, the small sample size within some species does not allow to infer in details the intra-specific variation, but we cannot rule out the possibility of an incipient differentiation between the M. magnusiana and M. rostrupii species at the molecular level (as well as in morphological traits).

The combination of the three molecular loci in a multigene phylogeny revealed that $M$. aecidioides, M. magnusiana, and M. rostrupii are clearly distinct from two other species of the M. populnea complex (M. larici-tremulae and $M$. pinitorqua). The M. populnea species complex seems to be divided in different groups depending on the spermogonial-aecial of the different species. M. pinitorqua and M. larici-tremulae alternate on conifers whereas the spermogonial-aecial of $M$. rostrupii and M. magnusiana is found on dicotyledonous plants. Pycnia and aecia of the third well differentiated species of this complex, M. aecidioides remains unknown (Arthur 1962). Only over-wintered bud-protected urediniospores have been observed for this species (Arthur 1962; Van Vloten 1946; Savile 1973). Further field investigations, based for example on inoculations and the molecular identification tool developed in this study, would help to determine if $M$. aecidioides is strictly autoecious (and confirm overwintering of $M$. aecidioides on poplars as the unique conservation form) and/or to eventually discover a putative aecial host.

Using our DNA barcode system, we highlighted species misidentification in specimens deposited in herbaria and sequences databases. The preliminary and systematic reexamination of herbarium specimens confirmed that most discrepancies between species identifications and those inferred from DNA barcodes were due to overlaps in host specificities and morphological characters for the uredinialtelial stage. For example, the morphometric data available to confirm the identity of this stage of $M$. abietis-canadensis proved insufficient and resulted in four herbarium specimen misidentifications. M. abietis-canadensis is known to occur on aspen, cottonwood, balsam, and white poplar in northcentral and northeastern North America, and to complete its heteroecious life cycle on hemlock (Arthur 1962; Sinclair \& Lyon 2005). We unambiguously identified the spermogonial-aecial stage of two strains of $M$. abietis-canadensis on Tsuga canadensis based on microscopic observations of typical small, ellipsoid to obovate aeciospores with fine verrucose surfaces (Arthur 1962; Ziller 1974). Another Melampsora species, M. farlowii (Arthur) Davis, also infects needles, green stems, and cones of $T$. canadensis but this species is autoecious and produces only telia and basidiospores (Hepting \& Toole 1939; Cummins \& Hiratsuka 2003; Sinclair \& Lyon 2005). One herbarium specimen collected on $P$. alba var. pyramidalis and initially described as $M$. abietis-canadensis showed strictly identical sequences to the strains identified as M. aecidioides. Similarly, its morphological, biological, and uredinial-telial host range led some authors to consider $M$. abietis-canadensis to be a form or even a synonym of M. medusae (Sinclair \& Lyon 2005; Tian \& Kakishima 2005). Three specimens collected on aspen and initially described as M. abietis-canadensis in the René Pomerleau Herbarium of the Laurentian Forestry Centre were considered in this study. Although the observed urediniospore lengths in these collections were generally more similar to those described for M. abietis-canadensis than for M. medusae (shorter length), the ITS, 28S, and 5'-CO1 sequences of these specimens were identical to those obtained for five M. medusae f. sp. tremuloidae strains.

Similarly, four additional ITS/28S sequences from M. magnusiana strains retrieved in the GenBank database were also included in this phylogenetic analysis and did not match those of the spermogonial-aecial strains of M. magnusiana. These strains were collected on P. alba, P. alba var. pyramidalis, and Populus tomentosa in China, and deposited in the Mycological Herbarium of the College of Forestry at the Northwest Sci-Tech University of Agriculture and Forestry in China (HMNWFC), and in the Mycological Herbarium of the Institute of Agriculture and Forestry at the University of Tsukuba in Japan (TSH) (Liang et al. 2006; Tian et al. 2004). The urediniospore morphologies and sizes described for these M. magnusiana isolates in Tian et al. (2004) (globose, ovate or oblong, 13.3-33.3 $\times 12.2-25.6 \mu \mathrm{m}$ [mean: $21.8 \times 17.6 \mu \mathrm{m}$ ], wall uniformly thick, 1.1-5.0 $\mu \mathrm{m}$ [mean: $2.8 \mu \mathrm{m}]$ ) matched the descriptions made for $M$. aecidioides, M. magnusiana, and M. rostrupii (Arthur 1962; Pinon 1973). Strong homology was found with 
each of the eight sequences of $M$. aecidioides. The distribution of this fungus on white poplars in Asia is concordant with previous records made on this continent (Cummins 1943; Tian \& Kakishima 2005).

\section{Conclusion}

This study reinforces the utility of DNA barcoding as an efficient tool for verifying taxonomic assignments of fungal pathogens. A combination of this approach with morphological characterisation showed that the Melampsora aecidioides species which occurs on Populus alba in North America is linked to the Melampsora populnea species complex but remains clearly differentiated from the other species found in the complex. In this study, we were specifically interested in seeing the effect of combining three genomic regions to resolve the studied Melampsora species. Although the combination of three genes may have increased the resolution, the ITS locus, used alone, provided with few exceptions a sufficiently clear gap between intra- and inter-specific divergence distributions to accurately differentiate these Melampsora species. A detection method based on a single locus, such as the ITS region, should therefore provide an acceptable compromise for a successful identification of these pathogens relative to the cost and time spent on PCR amplifications and sequencing of two additional loci. DNA barcoding provides a rapid standardized means to assess poplar leaf rust identities that will guide the application of adequate phytosanitary measures.

\section{Acknowledgments}

We thank the undergraduate student Héloïse Gagnon for technical assistance with fungal collection and molecular work; $\mathrm{Dr}$ Scott A. Redhead from the National Mycological Herbarium (DAOM), Dr Amy Rossman from U.S. National Fungus Collection (BPI), and Dr Pierre DesRochers from the Laurentian Forestry Centre for kindly providing herbarium specimens; and Marie-Josée Bergeron (Canadian Forest Service, Quebec City) for constructive reviews of the manuscript. This research was supported through funding to the Canadian Barcode of Life Research Network from Genome Canada through the Ontario Genomics Institute, NSERC, and other sponsors listed at www.BOLNET.org.

\section{Supplementary data}

Supplementary data associated with this article can be found, in the online version, at doi:10.1016/j.mycres.2009.02.007.

\section{R E F E R E N C E S}

Arthur JC, 1962. Manual of the Rusts in United States and Canada. Hafner Publishing Co., New York, NY.

Bagyanaryana G, 1998. The species of Melampsora on Populus (Salicaceae). In: Proceedings of the First IUFRO Rusts at Forest
Trees WP Conference, 2-7 Aug, 1998, Saariselka, Finland. Finnish Forest Research Institute, pp. 37-51 Research Papers 712.

Björkman E, 1964. Breeding for resistance to disease in forest trees. Unasylva 18: 71-81.

Cummins GB, 1943. Uredinales from the Northwest Himalaya. Mycologia 35: 446-458.

Cummins GB, Hiratsuka Y, 2003. Illustrated Genera of Rust Fungi, third edn. American Phytopathological Society, APS Press, St. Paul, MN.

Dabinett PE, Wellman AM, 1978. Numerical taxonomy of certain genera of fungi imperfecti and ascomycotina. Canadian Journal of Botany 56: 2031-2049.

Desprez-Loustau ML, 1986. Caractérisation morphologique et biologique des Melampsora spp. pathogènes des pins en Europe. European Journal of Forest Pathology 16: 360-374.

Desprez-Loustau ML, Dupuis F, 1992. A time-course study of teliospore germination and basidiospore release in Melampsora pinitorqua. Mycological Research 96: 442-446.

Desprez-Loustau ML, Robin C, Buée M, Courtecuisse R, Garbaye J, Suffert F, Sache I, Rizzo DM, 2007. The fungal dimension of biological invasions. Trends in Ecology and Evolution 22: 472-480.

Farr DF, Rossman AY, Palm ME, McCray EB, 2008. Fungal Databases. Systematic Mycology and Microbiology Laboratory, ARS, USDA, Available from: http://nt.ars-grin.gov/fungaldatabases/ (accessed 05.05.08).

Feau N, Hamelin RC, Bernier L, 2006. Attributes and congruence of three molecular data sets: inferring phylogenies among Septoria-related species from woody perennial plants. Molecular Phylogenetics and Evolution 40: 808-829.

Feau N, Hamelin RC, Bernier L, 2007. Variability of nuclear SSU-rDNA group I introns within Septoria species: incongruence with host sequence phylogenies. Journal of Molecular Evolution 64: 489-499.

Frey P, Gérard P, Feau N, Husson C, Pinon J, 2005. Variability and population biology of Melampsora rusts on poplars. In: Pei MH, McCracken AR (eds), Rust Diseases of Willow and Poplar. CABI Publishing, Wallingford, UK, pp. 63-72.

Freeland JR, 2006. Molecular Ecology. John Wiley \& Sons, West Sussex, UK.

Gardes M, Bruns TD, 1993. ITS primers with enhanced specificity for basidiomycetes-application to the identification of mycorrhizae and rusts. Molecular Ecology 2: 113-118.

Gower JC, 1971. A general coefficient of similarity and some of its properties. Biometrics 27: 857-871.

Hall TA, 1999. BioEdit: a user-friendly biological sequence alignment editor and analysis program for Windows 95/98/NT. Nucleic Acids Symposium Series 41: 95-98.

Hebert PDN, Cywinska A, Ball SL, deWaard JR, 2003. Biological identifications through DNA barcodes. Proceedings of the Royal Society of London B 270: 313-321.

Hennebert GL, 1964. L'identification des rouilles du peuplier. Agricultura Louvain 12: 661-670.

Hennen JF, McCain JW, 1993. New species and records of uredinales from the neotropics. Mycologia 85: 970-986.

Hepting GH, Toole ER, 1939. The hemlock rust caused by Melampsora farlowii. Phytopathology 29: 463-473.

Karlman M, 2001. Risks associated with the introduction of Pinus contorta in northern Sweden with respect to pathogens. Forest Ecology and Management 141: 97-105.

Klingström A, 1963. Melampsora pinitorqua (Braun) Rostr. Pine twisting rust. Some experiments in resistance-biology. Studia Forestalia Suecica 6: 1-23.

Longo N, Moriondo F, Naldini-Longo B, 1975. The status of M. pinitorqua Rostr. in Italy. European Journal of Forest Pathology 5: 147-152.

Liang Y-M, Tian C-M, Kakishima M, 2006. A new species of Melampsora on Populus yunnanensis from China. Mycoscience 47: 198-204.

Ludwig CA, 1915. Notes on some North American rusts with Caeoma-like sori. Phytopathology 5: 273-281. 
Maddison W, Knowles L, 2006. Inferring phylogeny despite incomplete lineage sorting. Systematic Biology 55: 21-30.

Molnar AC, Sivak B, 1964. Melampsora infection of pine in British Columbia. Canadian Journal of Botany 42: 145-158.

Moritz C, Cicero C, 2004. DNA barcoding: promise and pitfalls. PLoS Biology 2: 1529-1531.

Naldini-Longo B, Longo N, Moriondo F, Drovandi F, 1985. Observation on some Italian provenances of Melampsora populnea. I. Studies for identification of Melampsora pinitorqua and M. larici-tremulae. European Journal of Forest Pathology 15: 432-444.

Naldini-Longo B, Longo N, Drovandi F, Gonnelli T, Moriondo F, 1992. Observation on some Italian provenances of Melampsora populnea. II. Experiments on Melampsora pinitorqua and M. larici-tremulae present on Populus tremula in the same area. European Journal of Forest Pathology 22: 129-139.

Newcombe G, Ostry ME, Hubbes M, Périnet P, Mottet MJ, 2001. Poplar diseases. In: Dickman DI, Isebrands JG, Eckenwalder JE, Richardson J (eds), Poplar Culture in North America. NRC Research Press, National Research Council of Canada, Ottawa, ON, Canada, pp. 249-276.

Pei MH, Bayon C, Ruiz C, 2005. Phylogenetic relationships in some Melampsora rusts on Salicaceae assessed using rDNA sequences information. Mycological Research 109: 401-409.

Pinon J, 1973. Les rouilles du peuplier en France. Systématique et répartition du stade urédien. European Journal of Forest Pathology 3: 221-228.

Posada D, Crandall KA, 1998. MODELTEST: testing the model of DNA substitution. Bioinformatics 14: 817-818.

R Development Core Team, 2008. R: A Language and Environment for Statistical Computing. R Foundation for Statistical Computing, Vienna, Austria. http://www.R-project.org.

Roberts SM, Mitchell DT, 1979. Carbohydrate composition and invertase activity in poplar leaf tissues infected by Melampsora aecidioides (D.C.) Schroeter. New Phytologist 83: 499-508.

Saccardo PA, 1888. Sylloge Fungorum VII, p. 590.

Savile DBO, 1973. Rusts that pass import inspection. Canadian Plant Disease Survey 53: 105-106.

Seifert KA, Samson RA, deWaard JR, Houbraken J, Lévesque CA, Moncalvo J-M, Louis-Seize G, Hebert PDN, 2007. Prospects for fungus identification using CO1 DNA barcodes, with Penicillium as a test case. Proceedings of the National Academy of Sciences USA 104: 3901-3906.
Shain L, 1988. Evidence for Formae speciales in the poplar leaf rust fungus, Melampsora medusae. Mycologia 80: 729-732.

Sinclair WA, Lyon HH, 2005. Diseases of Trees and Shrubs, second edn. Cornell University Press, Ithaca, NY.

Sokal RR, 1986. Phenetic taxonomy: the theory and methods. Annual Review of Ecology and Systematics 17: 423-442.

Swofford DL, 2003. PAUP* phylogenetic analysis using parsimony ( ${ }^{*}$ and other methods) version 4 . Sinauer Associates, Sunderland, MA.

Thompson JD, Higgins DG, Gibson TJ, 1994. CLUSTAL W: improving the sensitivity of progressive multiple sequence alignment through sequence weighting, position-specific gap penalties and weight matrix choice. Nucleic Acids Research 22: 4673-4680.

Tian C-M, Shang Y-Z, Zhuang J-Y, Wang Q Kakishima M, 2004. Morphological and molecular phylogenetic analysis of Melampsora species on poplars in China. Mycoscience 45: 56-66.

Tian C-M, Kakishima M, 2005. Current taxonomic status of Melampsora species in China. In: Pei MH, McCracken AR (eds), Rust Diseases of Willow and Poplar. CABI Publishing, Wallingford, UK, pp. 99-112.

Tukey JW, 1977. Exploratory Data Analysis. Addison-Wesley, Boston, MA.

Van Vloten H, 1946. Is enrichment of the mycoflora possible? (with reference to Poplar rust). Review of Applied Mycology 25: 145-146.

Vilgalys R, Hester M, 1990. Rapid genetic identification and mapping of enzymatically amplified ribosomal DNA from several Cryptococcus species. Journal of Bacteriology 172: 4238-4246.

Waugh J, 2007. DNA barcoding in animal species: progress, potential and pitfalls. BioEssay 29: 188-197.

Wilson M, Henderson DM, 1966. The British Rust Fungi. Cambridge University Press, Cambridge, UK.

Ziller WG, 1961. Pine twist rust (Melampsora pinitorqua) in North America. Plant Disease Reporter 45: 327-329.

Ziller WG, 1962. Melampsora rust on Ponderosa pine. FAO Plant Protection Bulletin 10: 42-43.

Ziller WG, 1965. Studies of western tree rusts. VI. The aecial host ranges of Melampsora albertensis, M. medusae, and M. occidentalis. Canadian Journal of Botany 43: 217-230.

Ziller WG, 1974. The Tree Rusts of Western Canada. Canadian Forest Service, Pacific Forestry Centre, Victoria, BC. 